\title{
MASTEN
}

\section{A Geothermal Investigation of Spring and Well Waters of the Los Alamos Region, New Mexico}

$\frac{\pi}{E}$
$\frac{0}{0}$
$\frac{0}{0}$
$\frac{1}{0}$
$\frac{10}{0}$
$\frac{2}{5}$

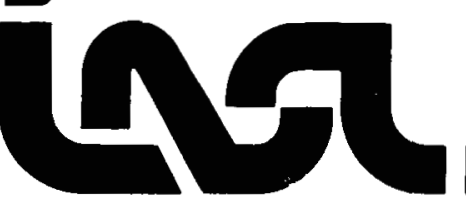


An Affirmative Action/Equal Opportunity Employer

This report was not edited by the Technical Information staff.

This report was prepared as an account of work sponsored by the United States Government. Neither the United States nor the United States Department of Energy, nor any of their employees, makes any warranty, express or implied, or assumes any legal liability or responsibility for the accuracy, completeness, or usefulness of any information, apparatus, product, or process disclosed, or represents that its use would not infringe privately owned rights. Reference herein to any specific commercial product, Reference herein to any specific commercial product,
process, or service by trade name, mark, manufacturer, or otherwise, does not necessarily constitute or imply its endorsement, recommendation, or favoring by the United States Government or any agency thereof. The views and opinions of authors expressed herein do not necessarily
state or reflect those of the United States Government or any agency thereof.

UNITED STATES DEPARTMENT OF ENERGY CONTRACT W-7408-ENG. 36 


\section{DISCLAIMER}

This report was prepared as an account of work sponsored by an agency of the United States Government. Neither the United States Government nor any agency Thereof, nor any of their employees, makes any warranty, express or implied, or assumes any legal liability or responsibility for the accuracy, completeness, or usefulness of any information, apparatus, product, or process disclosed, or represents that its use would not infringe privately owned rights. Reference herein to any specific commercial product, process, or service by trade name, trademark, manufacturer, or otherwise does not necessarily constitute or imply its endorsement, recommendation, or favoring by the United States Government or any agency thereof. The views and opinions of authors expressed herein do not necessarily state or reflect those of the United States Government or any agency thereof. 


\section{DISCLAIMER}

Portions of this document may be illegible in electronic image products. Images are produced from the best available original document. 
LA-8326-MS

Informal Report

UC-66a

Issued: April 1980

\section{A Geothermal Investigation of Spring and Well Waters of the Los Alamos Region, New Mexico}

Fraser E. Goff Suzanne Sayer*

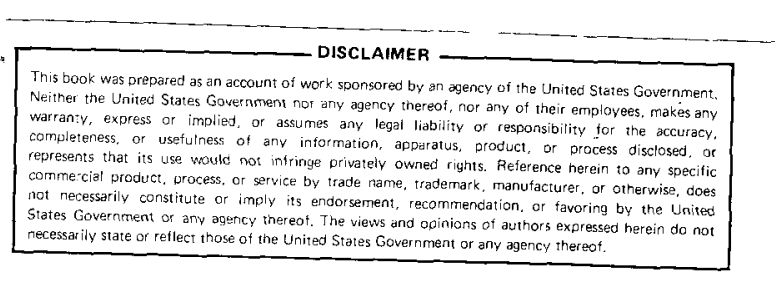

*University of California at Riverside, Riverside, CA 92502. 
A GEOTHERMAL INVESTIGATION OF SPRING AND WELL WATERS

OF THE LOS ALAMOS REGION, NEW MEXICO

by

Fraser E. Goff and Suzanne Sayer

\begin{abstract}
The chemical and isotopic characters of 20 springs and wells in the Los Alamos area were investigated for indications of geothermal potential. . These waters were compared with known hot and mineral springs from adjacent Valles Caldera and San Ysidro. All waters in the Los Alamos area are composed of meteoric water. Isotopic data show that the two primary aquifers beneath the Los Alamos region have different recharge areas. Relatively high concentrations of lithium, arsenic, chlorine, boron, and fluorine in some of the Los Alamos wells suggest these waters may contain a small fraction of thermal/mineral water of deep origin. Thermal water probably rises up high-angle faults associated with a graben of the Rio Grande rift now buried by the Pajarito Plateau.
\end{abstract}

\title{
INTRODUCTION AND SIMPLIFIED GEOLOGY/GEOPHYSICS
}

Los Al amos Scientific Laboratory has been evaluating geothermal potential of the Pajarito Plateau through geology and geophysics. The object of these studies is to locate and characterize geothermal resources, both conventional hydrothermal and hot dry rock, for use in space heating of the Laboratory. This report summarizes the geochemistry of local ground waters and some hot springs from adjacent Valles Caldera and presents some thoughts on the hydrology beneath the Pajarito Plateau. 
The Pajarito Plateau was formed from two copious ignimbrite sheets of Bandelier Tuff that erupted from Valles Caldera, a 1.1-Myr-old silicic volcano ${ }^{1}$ (Fig. 1). Precaldera dacite domes and derivative sediments of the Tschicoma and Puye formations underlie Bandelier Tuff on the west, whereas basalts and interbedded pyroclastics of Cerros del Rio underlie the tuff on the east. These relations are best exposed in Los Alamos Canyon near the Rio Grande. All of these volcanic units overlie a thick sequence of basin-fill sediments of the Santa Fe formation within the Española Basin of the Rio Grande rift. ${ }^{2}$ Many kilometers to the west and south, the Santa Fe formation and related Tertiary units overlie Mesozoic and Paleozoic layered sedimentary rocks. ${ }^{1,3}$ Southwest of Valles Caldera in San Diego Canyon, the stratigraphy consists of Paleozoic red-beds and carbonates that overlie Precambrian basement. ${ }^{4}$ The extent and thickness of Mesozoic and Paleozoic units beneath the Pajarito Plateau is unknown.

A detailed gravity survey by Budding ${ }^{5}$ shows that a graben filled with low density (Tertiary) sediments underlies the Pajarito Plateau. The indicated depth to Precambrian basement is roughly $3 \mathrm{~km}$, but the boundary between Tertiary and Mesozoic-Paleozoic rocks is uncertain. A time domain (geoelectric) survey of the Los Alamos area ${ }^{6}$ suggests that a low resistivity layer of approximately 7 ohm-m occupies the graben at a depth of 2 to $3 \mathrm{~km}$. These low resistivities could result from warm saline fluids in Paleozoic rocks at the bottom of the graben.

The Pajarito Plateau lies along the west margin of the Rio Grande rift where the regional heat flow is $2.7 \mathrm{HFU}^{7}$ Details about how large potable aquifers in the buried graben affect the regional heat flow are unknown. However, moderate thermal gradients of $20-40^{\circ} \mathrm{C} / \mathrm{km}$ in the Los Al amos area suggest that these cooler aquifers suppress the upward flow of heat. Heat flow in adjacent Valles Caldera locally exceeds $10 \mathrm{HFU} .^{8}$

\section{GEOCHEMISTRY OF WATERS}

No known hot or mineral springs discharge on the Pajarito Plateau, but abundant cold meteoric ground waters issue from surface rocks and flow in buried sands and gravels of the Santa Fe and Puye formations. The water quality of most of these waters has been investigated previously by Griggs and $\mathrm{Hem}^{9}$ and by Purtymun and Cooper. ${ }^{10}$ Thermal/mineral waters are rel atively abundant in the Valles Caldera area along San Diego Canyon and were studied in 


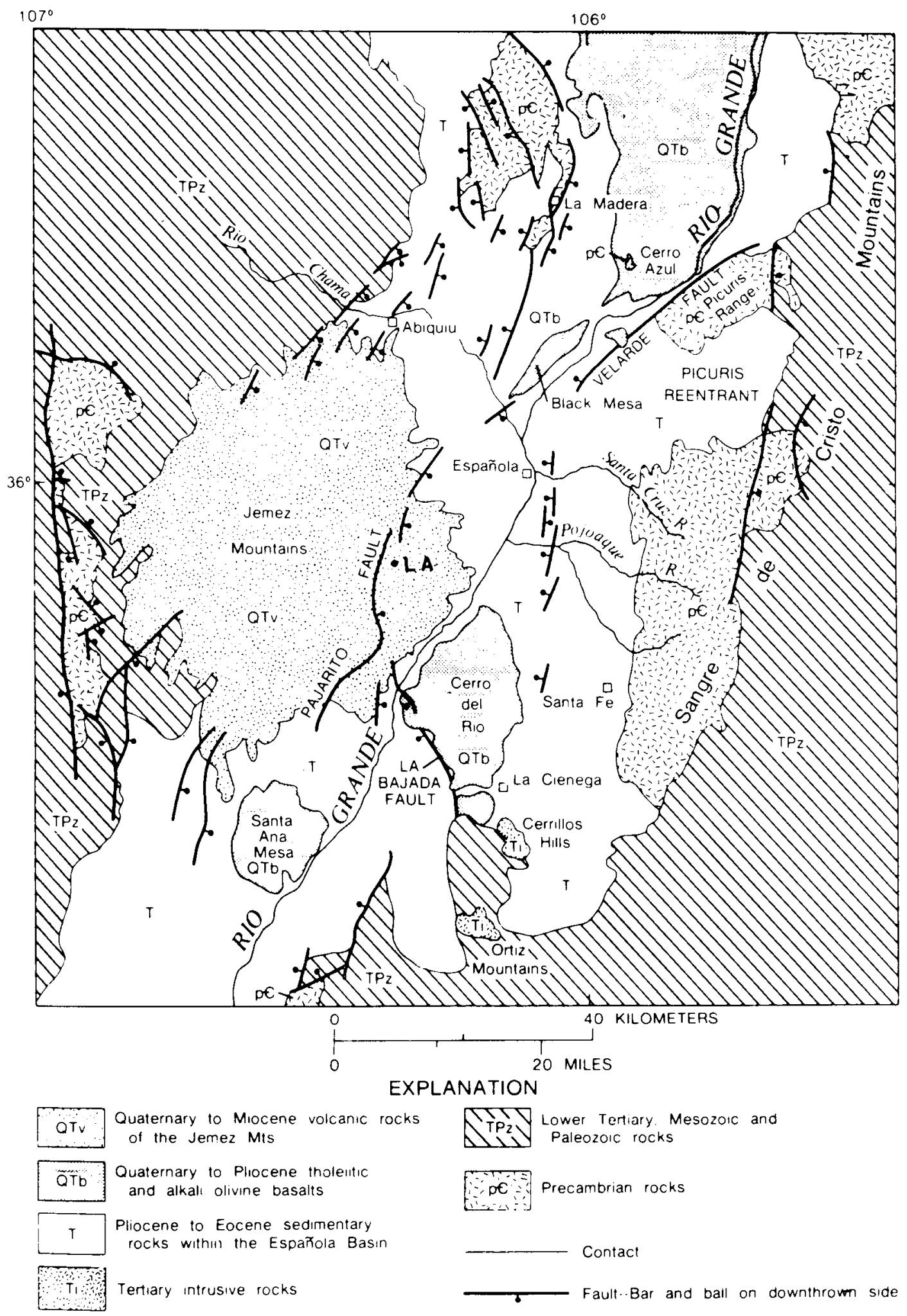

Fig. 1.

General geologic map of the Española Basin, Rio Grande rift, New Mexico (from Maniey, 1979); LA = Los Alamos. The Pajarito Plateau lies east of the Pajarito fault in center of map. 
recent years by Trainer ${ }^{11}$ and Purtymun et al. ${ }^{12}$ To aid in evaluating geothermal potential, 20 waters from the Los Alamos area and 6 thermal/mineral waters from Valles Caldera were analyzed for major element chemistry plus $D$ and ${ }^{18} 0$ isotopes (Fig. 2). The majority of Los Alamos samples come from relatively deep water supply wells that possibly tap aquifers containing a small fraction of thermal water of deep origin. The data from these samples appear in Tables I and II.

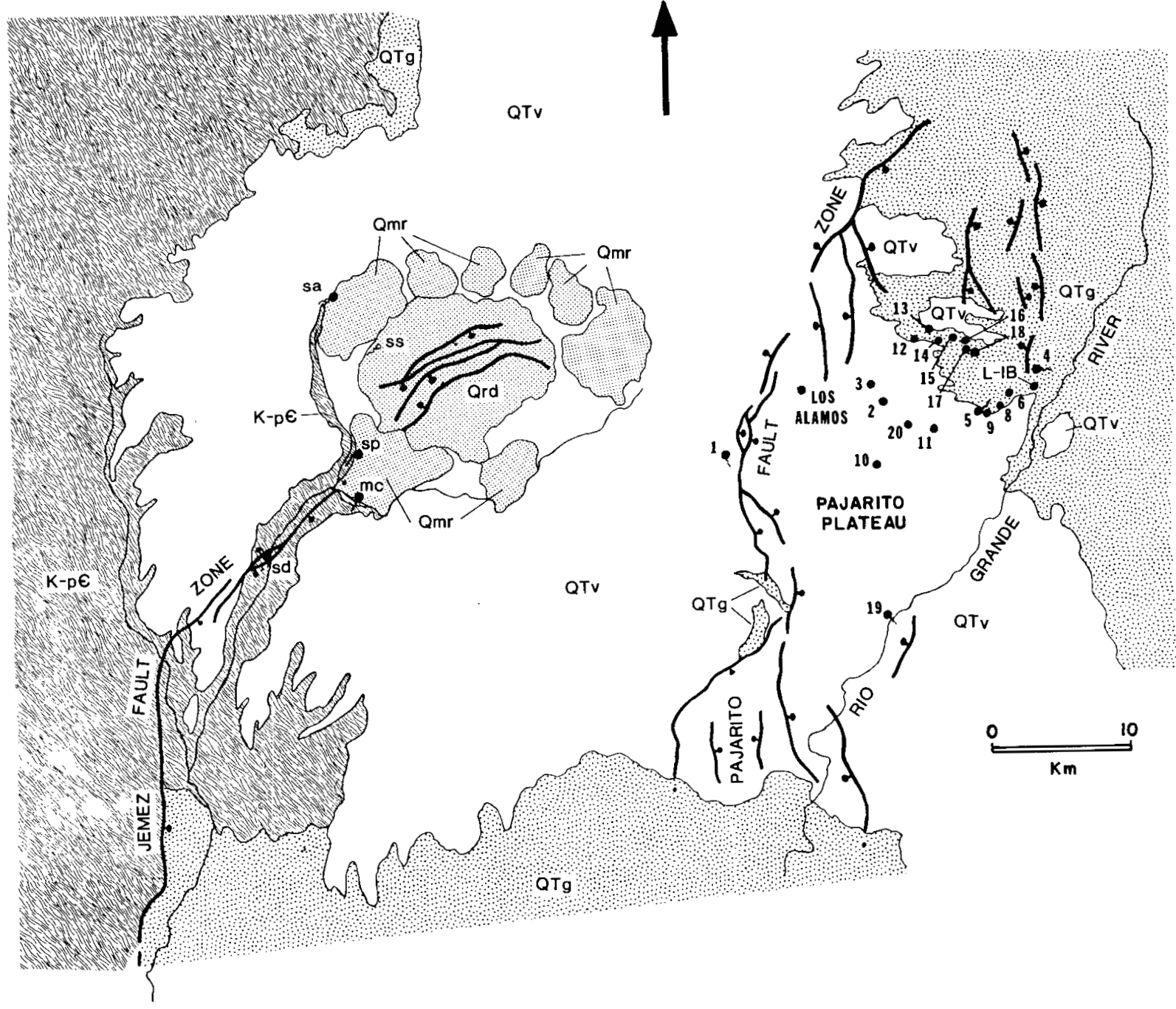

Fig. 2 .

Schematic geologic map of the Los Alamos area showing major faults; numbers refer to LA water samples in Table I. SA = San Antonio Hot Spring, SP = Spence Hot Spring, $M C=$ MCCauley Hot Spring, $S D=$ Soda Dam Spring, $S S=$ Sulphur Spring, Qrd = Resurgent Dome of Valles Caldera, Qmr = Moat Rhyolites of Valles Caldera, QTV = Quaternary-Tertiary volcanic rocks, QTg = Quaternary-Tertiary Sediments, $\mathrm{K}-\mathrm{p} \epsilon=$ Cretaceous-Precambrian bedrock . 
TABLE I

CHEMISTRY ANO FIELD CHARACTERISTICS OF 29 WATERS OF THE LOS ALAMOS AND VALLES CALDERA REgION, NEW MEXICO

\begin{tabular}{|c|c|c|c|c|c|c|c|c|c|c|c|c|c|c|c|c|c|c|c|}
\hline No. ${ }^{a}$ & Name & $\begin{array}{l}\text { Mea sured } \\
\text { Temp. } \\
\left({ }^{\circ} \mathrm{C}\right) \\
\end{array}$ & $\mathrm{SiO}_{2}$ & $\mathrm{Fe}$ & Mn & $\mathrm{Ca}$ & $\mathrm{Mg}$ & $\mathrm{Na}$ & $k$ & Li & $\underline{\mathrm{HCO}_{3}}$ & $\mathrm{SO}_{4}$ & $\mathrm{Cl}$ & $F$ & B & $\begin{array}{l}\text { Field } \\
\mathrm{pH}\end{array}$ & $\begin{array}{r}\text { Flow } \\
\text { Rate } \\
\text { l/min }\end{array}$ & $\begin{array}{l}\text { Rock } \\
\text { Type }\end{array}$ & $\begin{array}{c}\text { Depth } \\
\text { of Well } \\
\text { (m) }\end{array}$ \\
\hline VA-1 & Spence Hot Spg & 45 & 66 & $<0.04$ & $<0.02$ & 5.5 & 1.9 & 50 & 1.3 & 0.66 & 144 & 16 & 8 & 0.55 & 0.15 & 6.7 & 60 & A1 \& $V$ & \\
\hline VA-2 & Little Spence Hot Spg & 34 & 67 & $<0.04$ & $<0.02$ & 8.8 & 1.9 & 56 & 1.5 & 0.66 & 152 & 25 & 7 & 0.70 & 0.13 & 6.2 & 28 & Al \& $V$ & \\
\hline VA-3 & McCauley Spg & 31 & 56 & $<0.04$ & $<0.02$ & 8.5 & 4.9 & 18 & 0.8 & 0.24 & 86 & 7 & 6 & 0.85 & 0.24 & 6.2 & 140 & $V \& P$ & \\
\hline$V A-4$ & San Antonio Hot Spg & 42 & 79 & $<0.04$ & 0.02 & 2.3 & 0.30 & 21 & 1.7 & $<0.02$ & 56 & 7 & 2 & 0.80 & $<0.05$ & 6.8 & 160 & $v$ & \\
\hline$V A-5$ & Grotto Spg & 38 & 44 & 0.11 & 0.50 & 324 & 27 & 1000 & 174 & 13.2 & 834 & 41 & 1480 & 4.0 & 11.6 & 6.8 & 12 & P & \\
\hline$V A-6$ & Soda Dam Spg & 47 & 43 & 0.11 & 0.55 & 328 & 26 & 1010 & 174 & 13.2 & 886 & 37 & 1480 & 4.1 & 11.5 & 6.2 & 60 & $\mathrm{p}$ & \\
\hline LA-1 & Gallery Spg & 11 & 43 & $<0.04$ & $<0.02$ & 7.0 & 3.3 & 5.8 & 1.4 & 0.02 & 52 & $<5$ & $<1$ & 0.12 & $<0.05$ & 5.6 & 160 & $v$ & \\
\hline LA-2 & T-3 well & 12 & 15 & 0.53 & 0.11 & 14 & 5.0 & 11 & 1.9 & 0.03 & 102 & 5 & 4 & 0.26 & $<0.05$ & 6.5 & $0-12$ & Al \& $\mathrm{Pu}$ & 800 \\
\hline LA- 3 & T-2 well & 11 & 5 & $<0.04$ & $<0.02$ & 11 & 2.7 & 8.8 & 0.88 & 0.03 & 78 & 5 & 2 & 0.46 & $<0.05$ & 5.7 & $0-8$ & Al \& $\mathrm{Pu}$ & 49 \\
\hline LA-4 & Sacred Spg & 14 & 34 & $<0.04$ & $<0.02$ & 22 & 0.45 & 20 & 2.5 & 0.04 & 114 & 7 & 2 & 0.46 & $<0.05$ & 5.7 & Seep & SF & 55 \\
\hline LA-5 & Basalt Spg & 15 & 44 & $<0.04$ & $<0.02$ & 26 & 7.6 & 12 & 3.1 & 0.03 & 98 & 18 & 12 & 0.32 & $<0.05$ & 5.8 & 4 & $V \& \mathrm{Pu}$ & \\
\hline LA- 6 & L-6 wel 1 & 27 & 33 & $<0.04$ & $<0.02$ & 2.8 & 0.15 & 72 & 0.8 & 0.04 & 170 & 6 & 4 & 2.2 & $<0.05$ & 6.8 & $0-2160$ & SF & 625 \\
\hline LA-7 & L-1B well & 30 & 36 & $<0.0 \mathrm{~A}$ & $<0.02$ & 6.5 & 0.30 & 138 & 2.0 & 0.11 & 326 & 32 & 15 & 2.3 & 0.45 & 7.2 & $0-2180$ & SF & 694 \\
\hline LA-8 & L-5 well & 26.5 & 40 & $<0.04$ & $<0.02$ & 7.2 & 0.13 & 52 & 1.3 & 0.04 & 143 & 6 & 3 & 0.98 & $<0.05$ & 6.5 & $0-1880$ & SF & 623 \\
\hline LA-9 & L-4 well & 28 & 39 & $<0.04$ & $<0.02$ & 10 & 0.22 & 21 & 1.7 & 0.03 & 85 & 5 & $<1$ & 0.33 & 0.38 & 6.5 & $0-1560$ & SF & 622 \\
\hline LA-10 & PM-2 well & 23.5 & 83 & $<0.04$ & $<0.02$ & 8.8 & 3.0 & 9.6 & 1.7 & 0.02 & 65 & $<5$ & 3 & 0.19 & 0.25 & 6.5 & $0-5520$ & SF & 800 \\
\hline LA-1I & PM-1 well & 28 & 82 & $<0.04$ & $<0.02$ & 26 & 6.8 & 18 & 3.6 & 0.03 & 146 & 6 & 6 & 0.26 & 0.25 & 6.5 & $0-2320$ & SF & 770 \\
\hline LA-12 & G-6 well & 30.5 & 55 & $<0.04$ & $<0.02$ & 15 & 2.3 & 15 & 2.0 & $<0.02$ & 94 & 5 & 2 & 0.27 & $<0.05$ & 6.5 & $0-1100$ & $S F$ & 617 \\
\hline LA-13 & G-5 well & 26.5 & 59 & $<0.04$ & $<0.02$ & 17 & 3.9 & 11 & 1.8 & $<0.02$ & 93 & 5 & 2 & 0.25 & 0.12 & 6.5 & $0-2100$ & $S F$ & 614 \\
\hline LA- 14 & G-4 well & 26 & 53 & $<0.04$ & $<0.02$ & 16 & 2.5 & 14 & 1.8 & $<0,02$ & 92 & 5 & 2 & 0.27 & 0.12 & 6.5 & $0-1260$ & SF & 616 \\
\hline LA-15 & G-3 well & 29 & 59 & $<0.04$ & $<0.02$ & 11 & 1.2 & 22 & 1.6 & $<0.02$ & 93 & 5 & 2 & 0.45 & $<0.05$ & 6.5 & $0-1620$ & SF & 614 \\
\hline LA- 16 & G-2 well & 30 & 77 & $<0.04$ & $<0.02$ & 11 & 0.61 & 33 & 2.5 & 0.02 & 122 & 5 & 4 & 1.0 & 0.12 & 6.5 & $0-1820$ & SF & $617^{\circ}$ \\
\hline LA-17 & G-IA well & 28 & 78 & $<0.04$ & $<0.02$ & 11 & 0.58 & 24 & 2.8 & $<0.02$ & 100 & 5 & 1 & 0.55 & $<0.05$ & 6.5 & $0-2060$ & SF & 637 \\
\hline LA-18 & G-1 well & 26 & 84 & $<0.04$ & $<0.02$ & 13 & 0.68 & 22 & 3.1 & $<0.02$ & 97 & 5 & 1 & 0.50 & $<0.05$ & 6.5 & $0-1340$ & SF & 646 \\
\hline LA-19 & Spg, White Rack Can. & 19 & 7 & $<0.04$ & $<0.02$ & 12 & 3.1 & 11 & 1.4 & 0.03 & 74 & $<5$ & $<1$ & 0.45 & $<0.05$ & 6.5 & 6 & $v$ & \\
\hline LA-20 & PM-3 well & 27.5 & 91 & $<0.04$ & $<0.02$ & 26 & 8.7 & 16 & 3.3 & 0.04 & 146 & 6 & 12 & 0.28 & 0.18 & 6.5 & $0-5600$ & SF & 786 \\
\hline \multicolumn{20}{|c|}{ Mariner and others, 1977} \\
\hline & Unnamed Minera $1 \mathrm{Spg}$ & 11 & 18 & $<0.02$ & 0.05 & 220 & 110 & 3800 & 140 & 6.3 & 2265 & 3700 & 2700 & 2.0 & 8.0 & 7.27 & Seep & $\mathrm{p}$ & \\
\hline & Unnamed Warm Spg & 25 & 15 & 0.42 & 0.30 & 390 & 65 & 3000 & 91 & 5.2 & 1855 & 2600 & 2400 & 4.0 & 6.9 & 6.25 & $<20 ?$ & $\mathbf{P}$ & \\
\hline & Unnamed Mineral Spg & 15 & 20 & 0.14 & 0.57 & 300 & 68 & 2000 & 83 & 6.1 & 2005 & 1200 & 1900 & 3.4 & 11 & 6.33 & $<20$ ? & $\mathrm{P}$ & \\
\hline
\end{tabular}

all analyses by John Husler, University of New Mexico. Uniess otherwise noted, values reported in mg/l.

$\mathrm{b}_{\mathrm{Al}}=$ alluvium; $\mathrm{V}=$ volcanic rocks; $\mathrm{P}=\mathrm{Paleozoic}$ rocks; $\mathrm{SF}=$ Santa Fe formation; $\mathrm{Pu}=\mathrm{P}_{\mathrm{P}} \mathrm{ye}$ formation. 
TABLE II

DEUTERIUM, ${ }^{18} 0$, LITHIUM, ARSENIC, CHLORIDE, FLUORIDE, AND BORON OF 23 WATERS OF THE LOS ALAMOS AND VALLES CALDERA REGION, NEW MEXICO

By L. Merlivat, Dept. De Recherche et Analyse, Saclay, France

\begin{tabular}{|c|c|c|c|c|c|c|c|c|c|c|}
\hline \multirow[b]{2}{*}{ No. } & \multirow[b]{2}{*}{ Name } & \multirow{2}{*}{$\begin{array}{l}\text { Water } \\
\text { Type }\end{array}$} & \multirow{2}{*}{$\begin{array}{c}\text { Temp. } \\
{ }^{\circ} \mathrm{C}\end{array}$} & \multicolumn{2}{|c|}{ Per Mil } & \multicolumn{5}{|c|}{ Milligrams per Liter } \\
\hline & & & & $\delta \mathrm{D}$ & $\delta^{18} 0$ & $\mathrm{Li}$ & $A s^{b}$ & $\mathrm{Cl}$ & $F$ & $B$ \\
\hline$V A-1$ & Spence Hot Spg & $\mathrm{tm}$ & 45.0 & -86.4 & -12.35 & 0.66 & 0.072 & 8 & 0.55 & 0.15 \\
\hline VA-3 & McCautey Spg & $\mathrm{tm}$ & 31.0 & -88.4 & -12.60 & 0.24 & & 6 & 0.85 & 0.24 \\
\hline$V A-4$ & San Antonio Hot Spg & $\mathrm{tm}$ & 42.0 & -92.0 & -12.65 & $<0.02$ & & 2 & 0.80 & $<0.05$ \\
\hline$V A-5$ & Grotto Spg & $c$ & 38.0 & -84.6 & -10.65 & 13.20 & & 1480 & 4.00 & 11.60 \\
\hline VA-6 & Soda Dam Spg & c & 47.0 & -84.9 & -10.60 & 13.20 & 1.5 & 1480 & 4.10 & 11.50 \\
\hline LA-1 & Gallery Spg & $\mathrm{m}$ & 11.0 & -84.3 & -12.20 & $<0.02$ & & $<1$ & 0.12 & $<0.05$ \\
\hline LA-2 & T-3 well & m & 13.0 & -73.8 & -10.65 & 0.03 & & 4 & 0.26 & $<0.05$ \\
\hline$L A-3$ & T-2 well & $m$ & 11.0 & -73.5 & -10.60 & 0.03 & & 2 & 0.46 & $<0.05$ \\
\hline LA-4 & Sacred Spg & m & 14.0 & -81.8 & -11.80 & 0.04 & & 2 & 0.46 & $<0.05$ \\
\hline LA-5 & Basalt Spg & m & 15.0 & -76.5 & -10.85 & 0.03 & & 12 & 0.32 & $<0.05$ \\
\hline LA- 6 & L-6 well & m & 27.0 & -94.7 & -13.45 & 0.04 & $0.050-0.225$ & 4 & 2.20 & $<0.05$ \\
\hline $\mathrm{LA}-7$ & L-1B well & $m$ & 30.0 & -103.0 & -74.30 & 0.11 & $0.038-0.072$ & 15 & 2.30 & 0.45 \\
\hline$L A-10$ & PM-2 well & m & 23.5 & -77.5 & -11.40 & 0.02 & & 3 & 0.19 & 0.25 \\
\hline LA-11 & PM-l well & m & 28.0 & -74.1 & -10.95 & 0.03 & & 6 & 0.26 & 0.25 \\
\hline$L A-12$ & G-6 wei1 & m & 30.5 & -76.0 & -11.25 & $<0.02$ & & 2 & 0.27 & $<0.05$ \\
\hline LA- 14 & G-4 well & $\mathrm{m}$ & 26.0 & -76.3 & -71.10 & $<0.02$ & & 2 & 0.27 & 0.12 \\
\hline$L A-14$ & G-2 wel1 & m & 30.0 & -83.1 & -11.95 & 0.02 & & 4 & 1.00 & 0.12 \\
\hline LA- 17 & G-1A well & $\mathrm{m}$ & 28.0 & -82.5 & -11.80 & $<0.02$ & & 1 & 0.55 & $<0.05$ \\
\hline LA-18 & G-1 well & m & 26.0 & -81.0 & -11.65 & $<0.02$ & & 1 & 0.50 & $<0.05$ \\
\hline LA-19 & Spg, White Rock Can & $\mathrm{m}$ & 19.0 & -76.8 & -11.00 & 0.03 & & $<1$ & 0.45 & $<0.05$ \\
\hline \multirow[t]{4}{*}{ Mariner } & and others, 1977 & & & & & & & & & \\
\hline & Unnamed Mineral Spg & $c$ & 11.0 & -85.6 & -10.01 & 6.30 & & 2700 & 2.00 & 8.00 \\
\hline & Unnamed Warm Spg & c & 25.0 & -90.1 & -11.22 & 5.20 & 0.60 & 2400 & 4.00 & 6.90 \\
\hline & Unnamed Mineral Spg & c & 15.0 & -86.5 & -10.12 & 6.10 & & 1900 & 3.40 & 11.00 \\
\hline
\end{tabular}

\footnotetext{
$a_{t m}=$ thermal meteoric

$c=$ probable connate

$m=$ surface meteoric
}

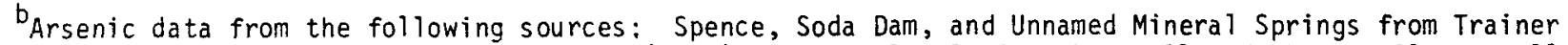
(1974); Wells L-1B and L-6 from Purtymun (1977); Arsenic levels in other wells of the Los Alamos well field are $<0.030 \mathrm{mg} / \mathrm{l}$. 
Methods and Procedures

Temperatures were recorded with mercury thermometers and field pH was determined using sensitive limited-range pH test papers (Colorfast Indicator Strips nos. 9581, 9582, and 9583). The pH values are considered reliable to $\pm 0.25 \mathrm{pH}$ units in the 6.5 to $7.0 \mathrm{pH}$ range; values outside this range are considered reliable to $\pm 0.15 \mathrm{pH}$ unit. Laboratory values of $\mathrm{pH}$ are not considered reliable because most waters gain or lose $\mathrm{CO}_{2}$ gas after sampling and before laboratory analysis. This alters the concentration of bicarbonate ions, which in turn changes the $\mathrm{pH}$. Flow rates of springs were estimated visually; flow rates of wells were obtained from gauges on the wellhead.

Samples of water for chemical analysis were filtered using a large syringe attached to a filter holder containing $0.8 \mu$ filter paper. The filtered water was squirted brimful into polyethylene bottles with polyseal caps. Three types of samples were collected: (1) a 500-me bottle of filtered unacidified water for anions, (2) a 250-me bottle of filtered acidified water for cations, and (3) a 125-me bottle of filtered diluted water for silica. Dilute hydrochloric acid was added dropwise to the acidified sample until the $\mathrm{pH}<2$. The bottles used for silica analyses contained $90 \mathrm{me}$ of deionized water before $10 \mathrm{me}$ of sample were added. This dilution prevents polymerization of monomeric silica in more concentrated water samples before analysis.

Laboratory analyses were performed by the following methods: $\mathrm{SiO}_{2}$, $\mathrm{Fe}$, $\mathrm{Mn}, \mathrm{Ca}, \mathrm{Mg}, \mathrm{Na} \mathrm{K}$, and $\mathrm{Li}$ by atomic absorption spectroscopy; $\mathrm{HCO}_{3}$ by sulfuric acid titration, $\mathrm{SO}_{4}$ by turbidimetric titration using $\mathrm{BaCl}_{2} ; \mathrm{Cl}$ by titration using $\mathrm{AgNO}_{3}$; $\mathrm{F}$ by specific ion electrode, and $\mathrm{B}$ by colorimetric methods with carminic acid. Results appear in Table $I$ in values of $\mathrm{mg} / \ell$.

Samples for $D$ and ${ }^{18} 0$ analysis were collected by filling 125 -me glass bottles full of raw water and sealing with a Polyseal cap. Isotope variations were determined by standard methods and the data appear in Table II. Hydrogeology

The hydrology of the Pajarito Plateau was determined by Purtymun and Johansen $^{13}$ (Fig. 3) from their studies of many deep water supply wells. Although the plateau dips gently eastward toward the Rio Grande, the underlying sediments of the Santa Fe formation dip westward toward Valles Caldera (Fig. 4). The main aquifer in the Los Alamos area dips very gently eastward at depths of 185 to $370 \mathrm{~m}$ beneath the surface of the plateau. The source of water lies undoubtedly in the Jemez Mountains. Because the Santa Fe sediments 


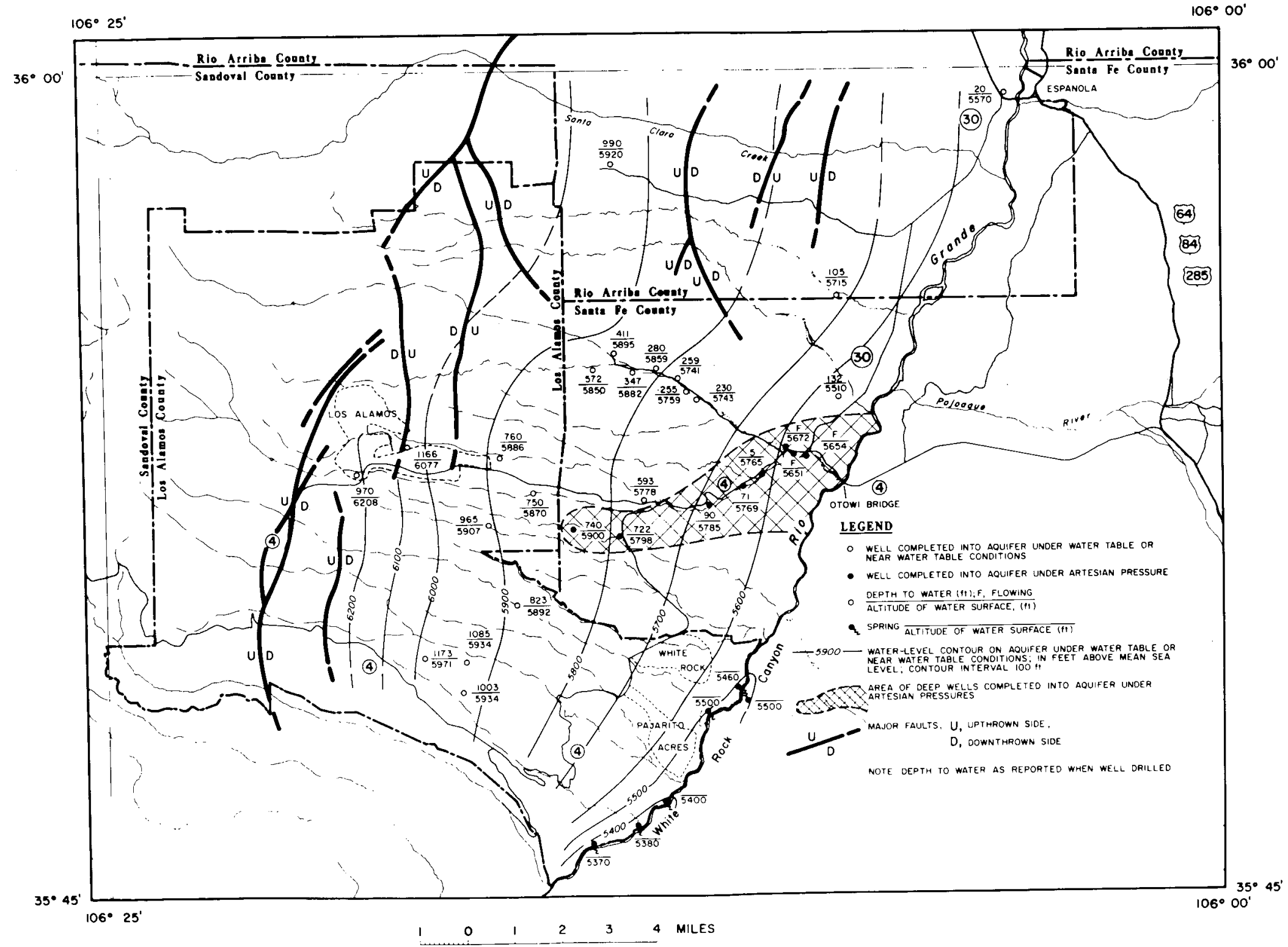

Fig. 3 .

Hydrologic map of the Pajarito Plateau showing generalized contours of the main aquifer and location of confined (artesian) aquifer (from Purtymun and Johansen, 1974). 
dip to the west, the main aquifer must cross lithologic boundaries (that is, bedding $\mathrm{planes)}$ as the water migrates to the east. Wells of the Los Alamos well field are completed into a confined aquifer and yield water under artesian pressure. This confined aquifer probably has its source to the east as suggested by the isotope data described below. The depths of the wells and the rocks that yield water are summarized in Table I. The rock types from which the springs emerge are al so listed in Table I.

Geochemistry

The chemical composition of the various waters are displayed in Fig. 5. The 20 Los Alamos samples range from calcium and magnesium to sodium bicarbonate water. The dilute hot springs chemically resemble the LoS Alamos waters. Spence and San Antonio Hot Springs are comprised of sodium bicarbonate water whereas McCauley Spring, a warm spring, contains relatively higher calcium and magnesium. In contrast, Soda Dam and Grotto Springs, which are hot mineral springs, contain appreciable chloride and thus are chemically distinct from the other waters of this study.

Isotopes. The $\mathrm{D}$ and ${ }^{18} 0$ isotope compositions of the waters are shown in Fig. 6 and Table II. All 20 Los Alamos samples plot along the Craig Meteoric Line as do the dilute hot springs, indicating that they are all composed of meteoric water.

However, Soda Dam, Grotto Springs, plus three mineralized springs near San Ysidro are significantly richer in ${ }^{18} 0$ than meteoric waters. Because of their relatively high chloride content and origin in marine sediments, the mineral waters may be composed partly of connate water, a derivative of ancient sea water. Connate waters are enriched in ${ }^{18} 0$ relative to meteoric water. ${ }^{14}$

Deep geothermal fluids are al so enriched in ${ }^{18} 0$ by virtue of isotope exchange of water with very hot rock. ${ }^{15}$ The waters of Soda Dam and Grotto Springs may contain a fraction of deep geothermally heated water because of their close proximity to Valles Caldera, but the San Ysidro mineral springs, which lie many kilometers to the south and west, probably do not.

Although well waters $L-1 B$ and $L-6$ are composed of meteoric water, they are relatively lighter in both $D$ and ${ }^{18} 0$ than other meteoric waters, suggesting a source of water to the east (farther from the ocean). The hydrologic data of Purtymun and Johansen ${ }^{13}$ (Fig. 3) indicate that waters of the Los Alamos well field originate from a confined aquifer in westward dipping Santa Fe formation sediments. The artesian water in this confined aquifer probabiy 
LOS ALAMOS,

PAJARITO PLATEAU

RIO GRANDE

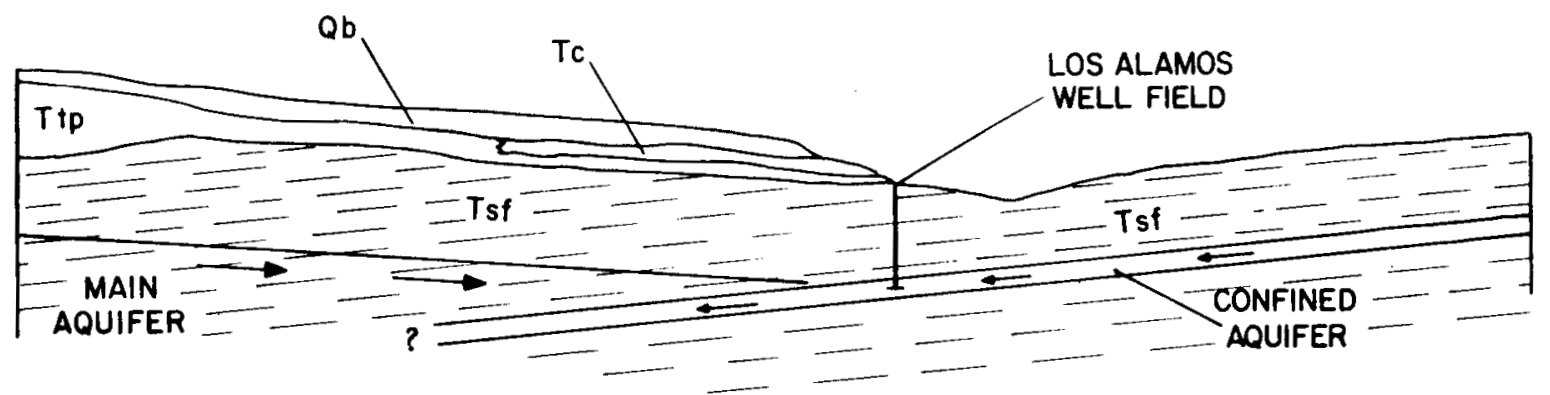

Fig. 4.

Schematic cross section of Pajarito Plateau showing simplified model of main and confined aquifers. $Q b=$ Bandelier Tuff, $T C=$ Cerros del Rio Basalt, Ttp $=$ Tschicoma and Puye formations, Tsf = Santa Fe formation. Surfaces of main aquifer crosses bedding (dashed lines) of Santa Fe formation.

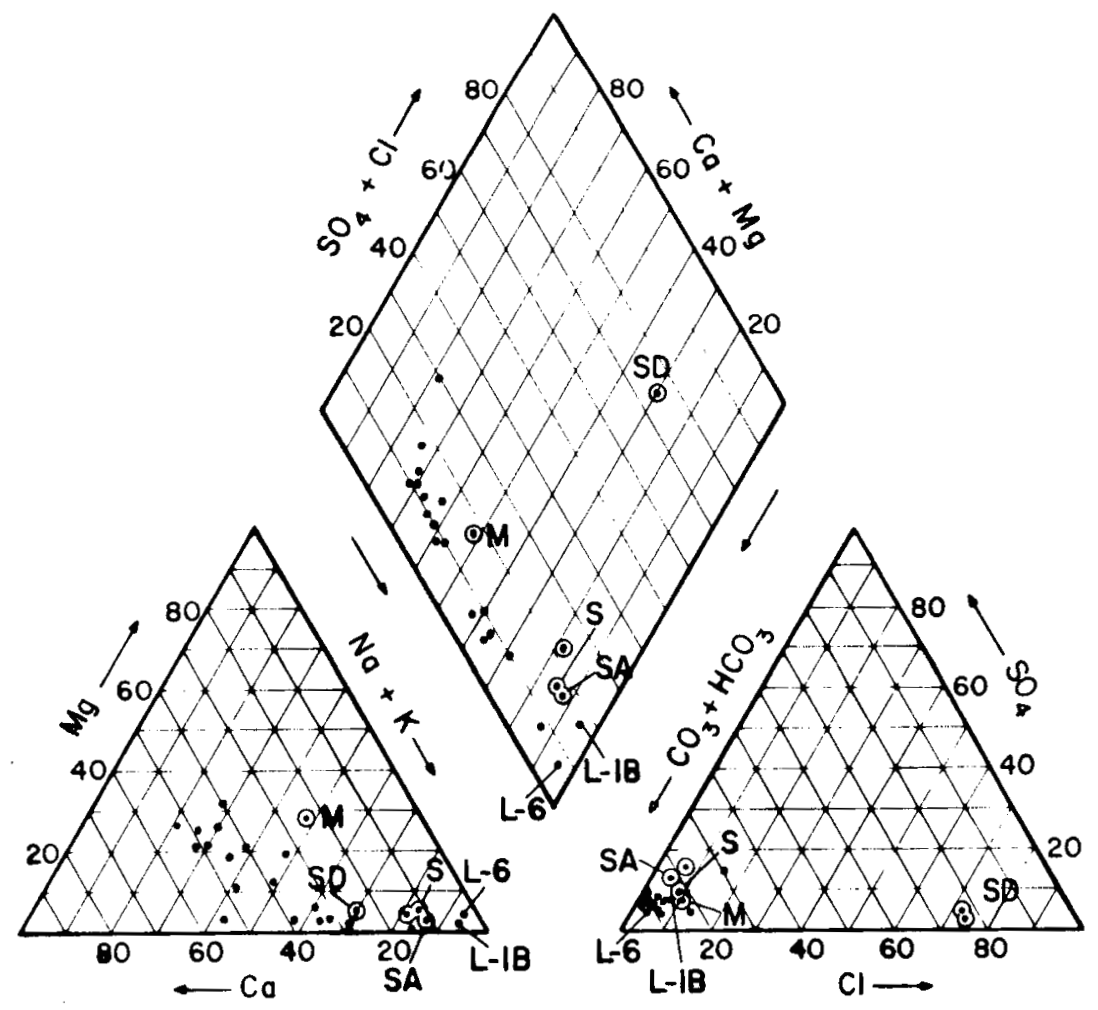

Fig. 5 .

Piper diagram showing the chemical composition in equivalents of 26 thermal and nonthermal waters in the Los Alamos-Valles Caldera region, New Mexico; $\odot=$ thermal waters, $\bullet=$ nonthermal waters, $S A=$ San Antonio Hot Spring, $M=$ McCauley Spring, $S=$ Spence Hot Spring, $S D=$ Soda Dam Spring, $L-1 B$ and $L-6=$ wells from Los Alamos well field. 
comes from the east as suggested by the isotope data. Also, the isotopes suggest that well L-6 is a mixture of the main aquifer beneath Los Alamos and the confined aquifer.

Silica. The silica data (Fig. 7) show that the thermal meteoric and mineral springs have two different trends. Both show increasing silica with increasing temperature, but the mineralized waters contain substantially less silica. This may be due to the different bedrock types associated with these waters. The mineral springs originate in part from Paleozoic limestones, whereas the thermal meteoric waters issue from silica-rich Quaternary rhyolites. Cold meteoric well waters of the Los Alamos area fall into groups in Fig. 7, probably because of variations of their local source aquifers. Note, however, that silica concentration is independent of temperature for the deep wells even though all waters originate in sands and gravels of the Santa Fe formation. The relatively shallow T-2 and T-3 wells contain the least silica, perhaps caused by the combined effects of cooler temperature and shorter residence time of water in the rocks. Unlabeled points represent data for Los Alamos springs; those discharging from volcanic rocks contain more silica than Sacred Spring, which issues from Santa Fe gravels.

Chloride. A plot of chloride vs measured temperature appears in Fig. 8. The mineral springs contain 3 orders of magnitude more chloride than other waters of this study, but interestingly, the mineral waters display decreasing chloride with increasing temperature.

Thermal meteoric waters and meteoric waters of the Los Alamos area contain equivalent amounts of chloride. Only one group of well waters from the silica plot forms a group on the chloride plot (G-3 to G-6 wells). Well L-1B contains more chloride than all other meteoric waters of this study.

Trace Elements. Thermal waters are commonly enriched in lithium, arsenic, chloride, fluoride, and boron relative to cold meteoric waters; in particular, high ratios of lithium/chloride and boron/chloride often suggest a deep thermal origin of the waters. 16

The lithium and boron data (Figs. 9 and 10) show that the mineral and thermal meteoric waters contain more lithium and boron than most cold meteoric waters of the Los Alamos area. The thermal meteoric waters have higher 1 ithium/chloride and boron/chloride ratios than the mineral springs. Water supply well L-1B contains above-background concentrations of both boron and lithium; in fact, it contains more boron than any of the thermal meteoric waters, which 


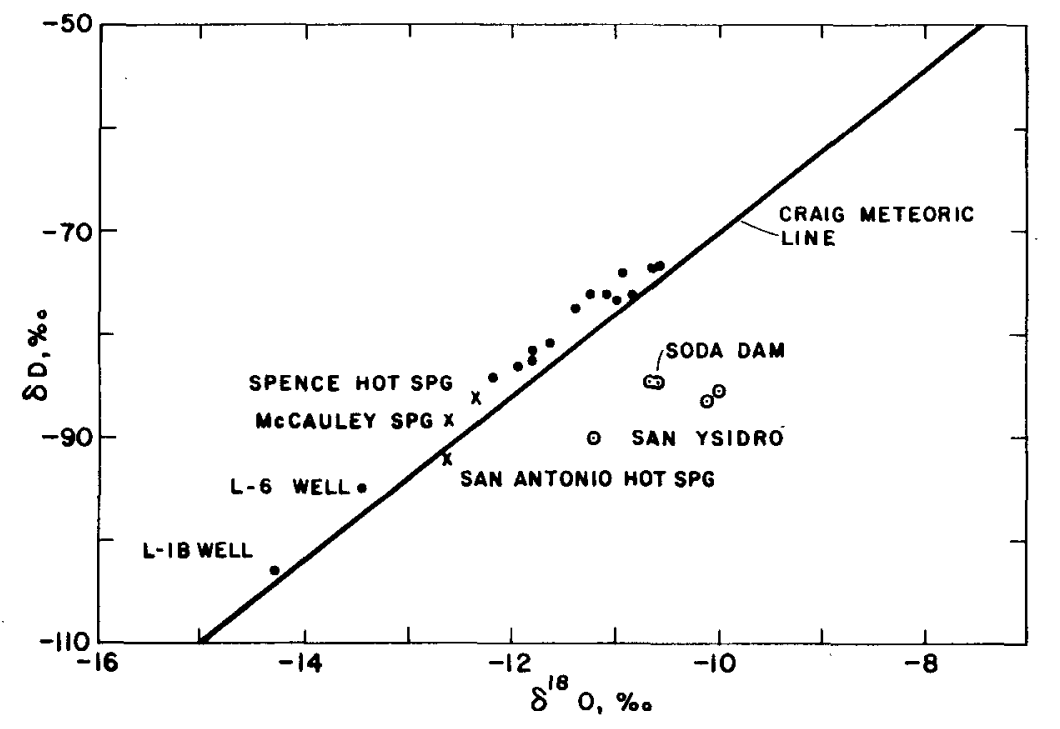

Plot of $\delta D$ vs $\delta^{18} 0$ for 23 thermal and nonthermal waters of the Los Alamos-Valles Caldera region, New Mexico; $\odot=$ thermal/mineral waters, $X=$ thermal meteoric waters, $\bullet=$ cold meteoric waters; data for San Ysidro mineral springs from Mariner et a1. (1977).

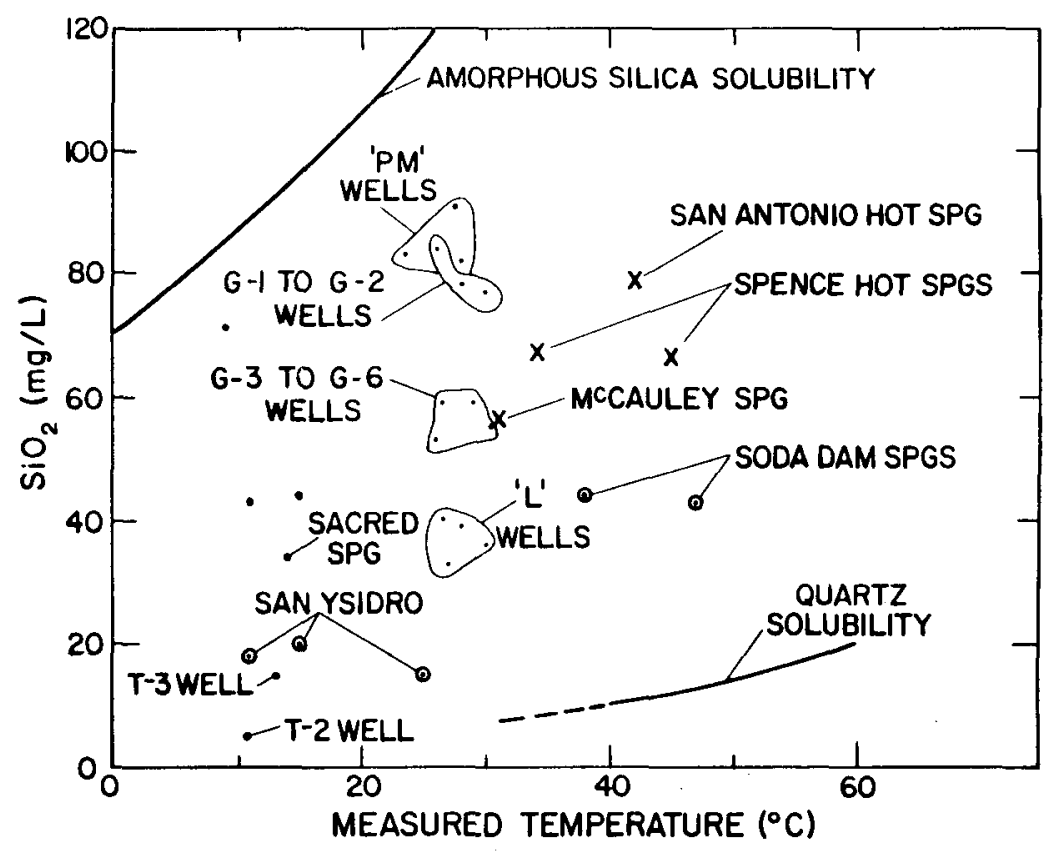

Fig. 7.

Plot of $\mathrm{SiO}_{2}$ vs measured temperature for thermal and nonthermal waters of the Los Alamos-Valles Caldera region, New Mexico; data and symbols same as Fig. 6 . 


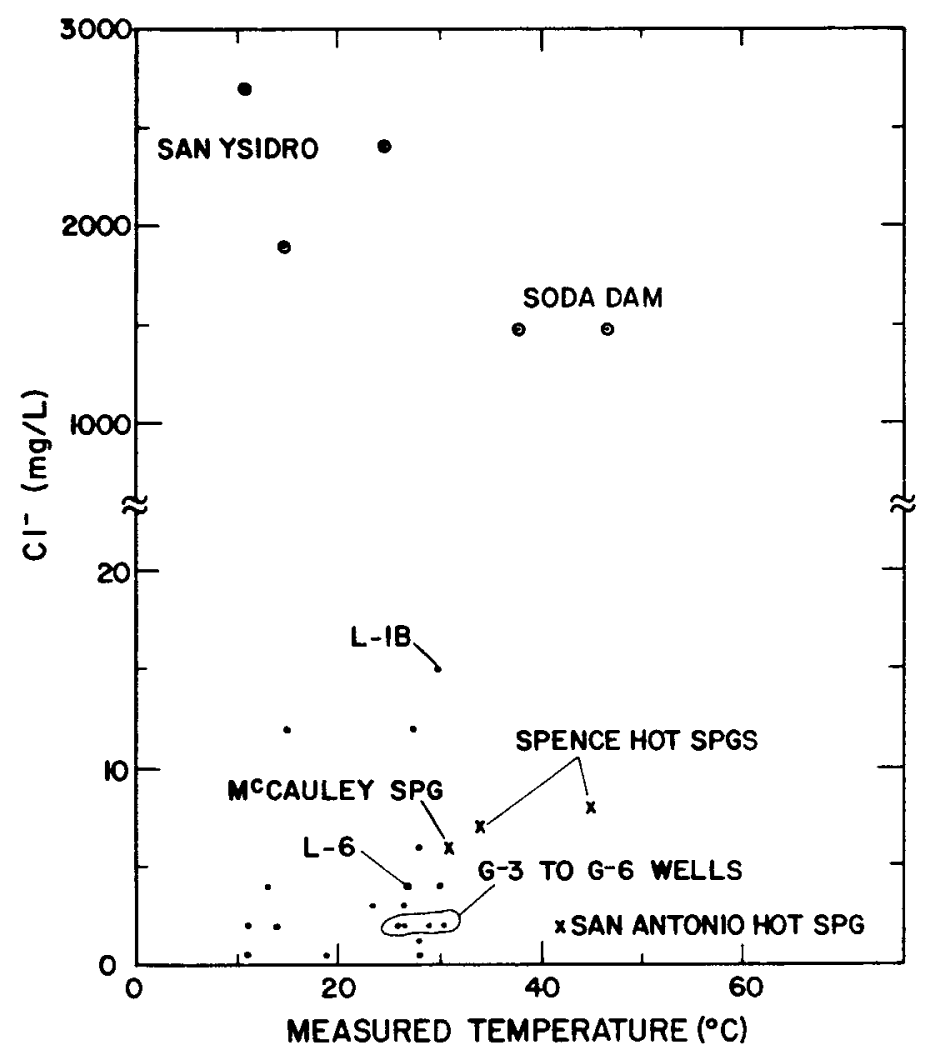

Fig. 8.

Plot of chloride vs measured temperature for thermal and nonthermal waters of the Los Alamos-Valles Caldera Region, New Mexico; data and symbols same as Fig. 6

suggests that it may contain a small fraction of thermal/mineral water of deep origin.

Water supply well L-1B is also anomalously high in both fluoride and arsenic compared with other cold meteoric of the Los Alamos area (Figs. 11 and 12). This again suggests that a small component of water of deep origin has mixed with the aquifer tapped by L-1B.

Chemical Geothermometry

Subsurface aquifer temperatures of hot water. geothermal systems can be estimated using the concentrations of temperature-dependent species such as silica and sodium, potassium, and calcium. ${ }^{17,18}$ Several assumptions must be satisfied, however, before the direct application of the geothermometers has any meaning. These include water-rock equilibrium at depth, negligible reequilibration as the water rises toward the surface, and no mixing of deep hot 


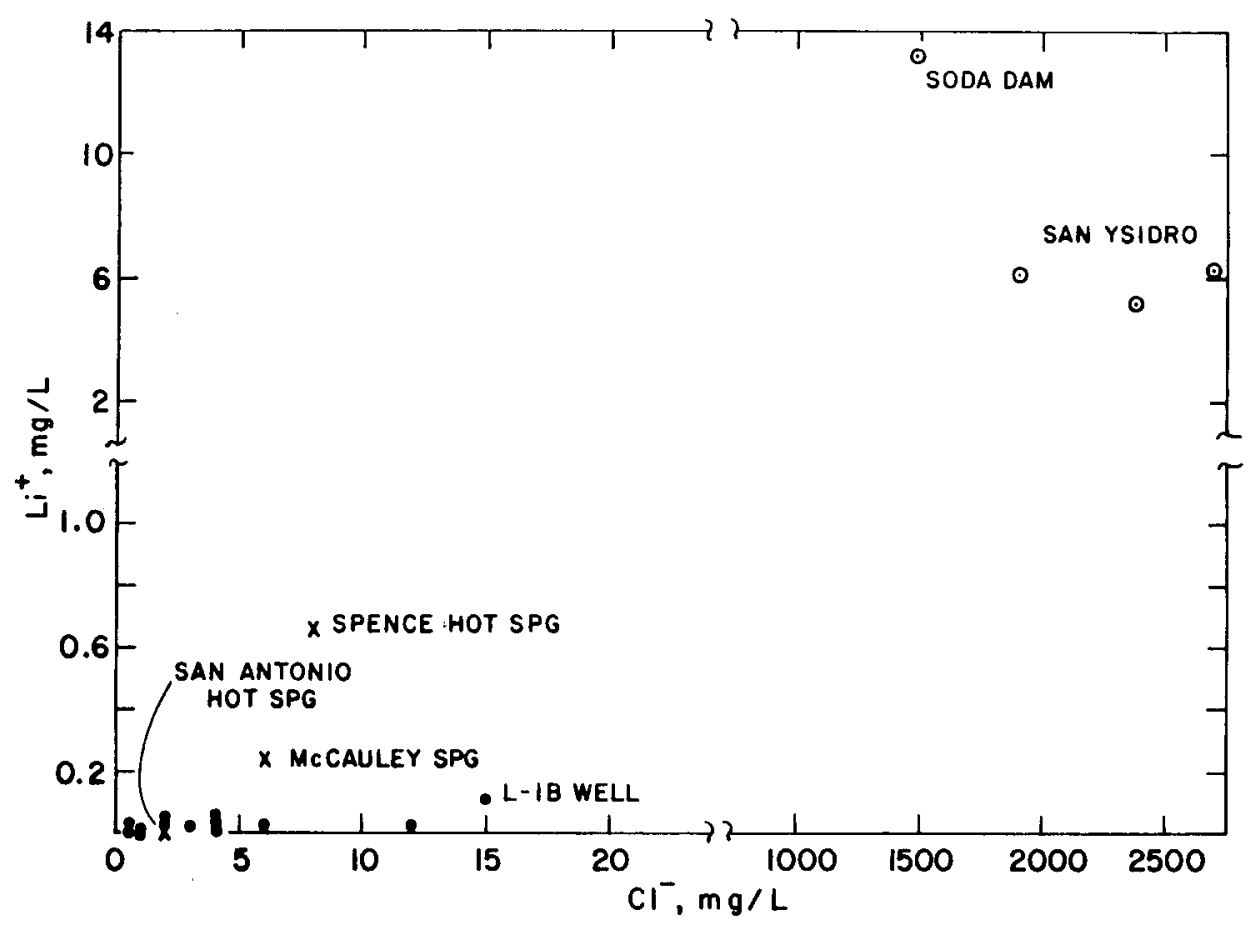

Fig. 9.

Plot of lithium vs chloride for thermal and nonthermal waters in the Los AlamosValles Caldera region; data and symbols same as Fig. 6.

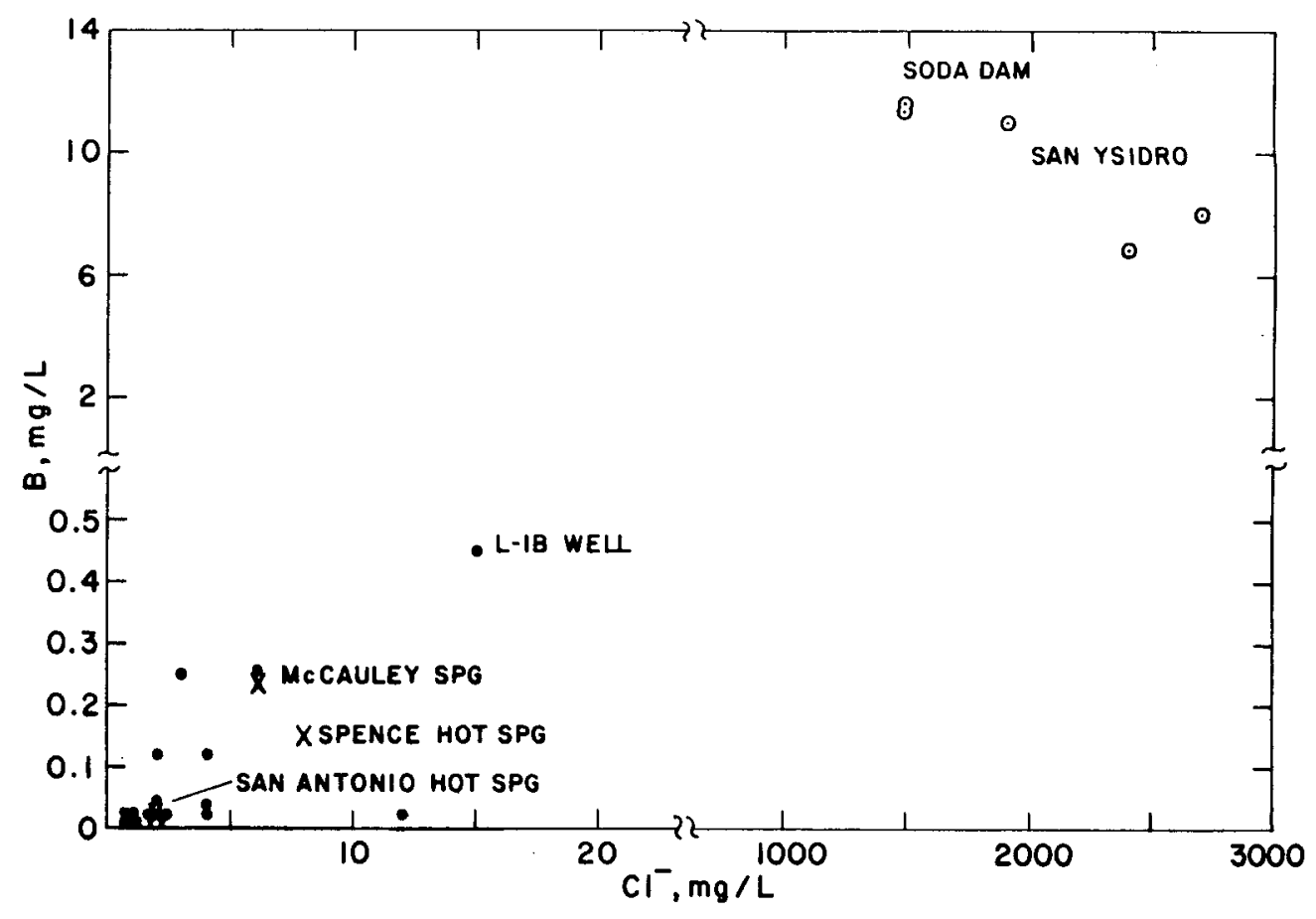

Fig. 10 .

Plot of boron vs chloride for thermal and nonthermal waters in the Los AlamosValles Caldera region; data and symbols same as Fig. 6. 


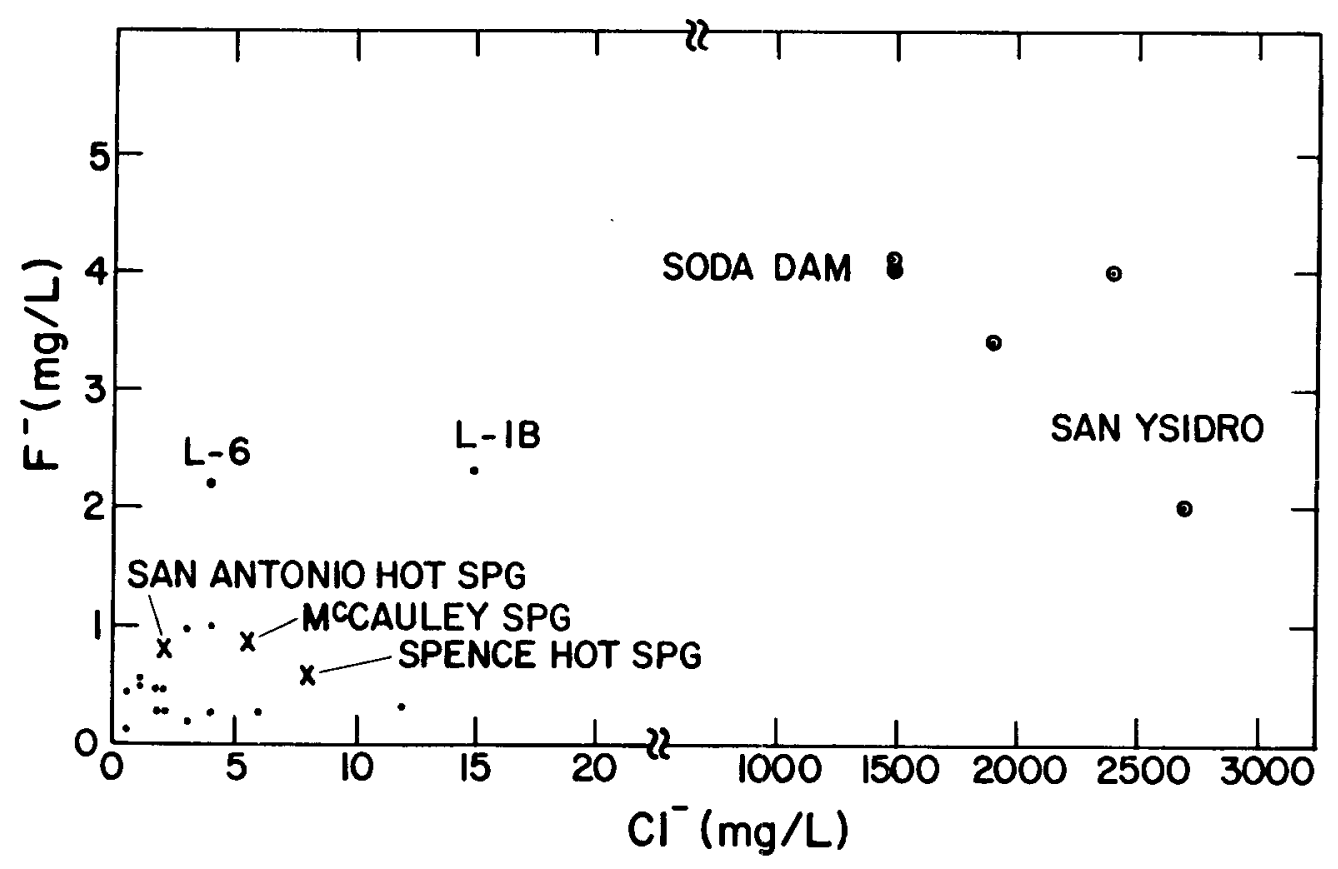

Fig. 11 .

Plot of fluoride vs chloride for thermal and nonthermal waters in the Los AlamosValles Caldera region; data and symbols same as Fig. 6.

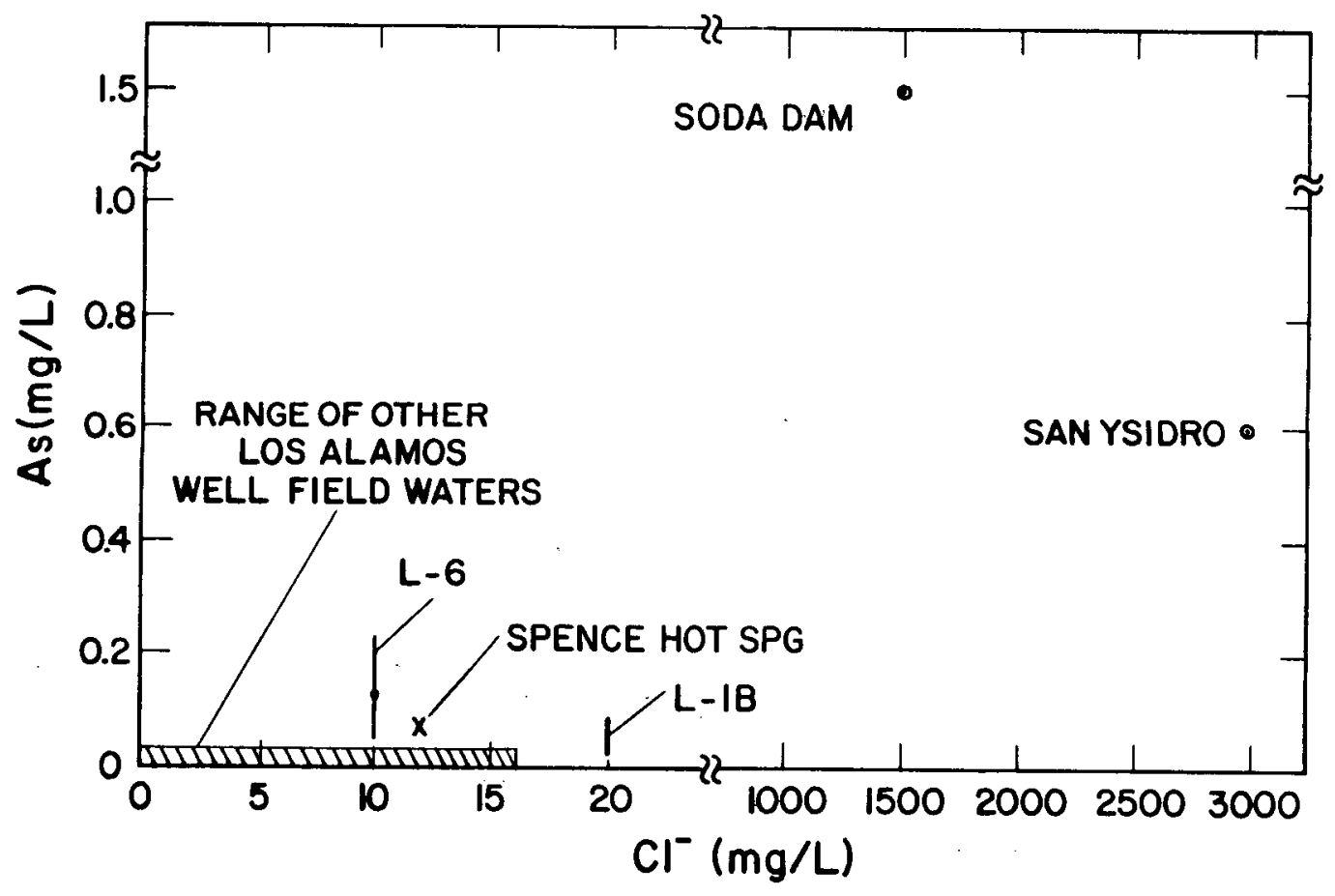

Fig. 12.

Plot of arsenic vs chloride for thermal and nonthermal waters in the Los AlamosValles Caldera region; arsenic data from Trainer (1974) and Purtymun (1977); symbols same as Fig. 6. 
and cold surface waters. Because of such restraints, the application of the geothermometers to real systems may be very difficult.

The Na-K-Ca geothermometer of Fournier and Truesdel1 18 contains a factor, $B$, that is dependent on whether or not the water equilibrated above $100^{\circ} \mathrm{C}(\beta=$ $1 / 3)$ or below $100^{\circ} \mathrm{C}(\beta=4 / 3)$. Their equation was derived by considering reactions that involve feldspars, thus the geothermometer is most reliable for igneous and metamorphic terrains where ample feldspar is available for reaction. The $\beta=1 / 3$ case is not considered reliable if the $\beta=4 / 3$ temperature is less than $100^{\circ} \mathrm{C}$, the $\log \left(\mathrm{Ca}^{1 / 2} / \mathrm{Na}\right)$ in equivalents is positive, or if the water contains high concentrations of magnesium. A magnesium correction procedure for this geothermometer has been published recently, ${ }^{19}$ which is applicable if the $\mathrm{Na}-\mathrm{K}-\mathrm{Ca}$ temperature is $>70^{\circ} \mathrm{C}$ and the factor $\mathrm{R}=\mathrm{Mg} /(\mathrm{Mg}+\mathrm{Ca}+\mathrm{K}) \times$ 100 in equivalents $<50$.

Table III lists the temperature estimates of the thermal/mineral waters plus water supply wells $L-1 B$ and $L-6$. All waters are undersaturated with respect to amorphous silica and oversaturated with respect to quartz, except possibly the T-2 well (Fig. 7). Possibly the waters are in equilibrium with some intermediate silica phase such as chalcedony or cristobalite. The Na-K-Ca temperature estimates are probably more reliable because, in the case of meteoric waters, they are generally within $\pm 25^{\circ} \mathrm{C}$ of the measured temperatures. 20

\section{EVALUATIONS OF GEOTHERMAL POTENTIAL}

The evaluations that follow serve as a comparison between the known Valles thermal/mineral springs and spring and well waters of the Los Alamos area. Because of the limited data, they should be considered tentative.

Thermal meteoric waters--Spence, San Antonio, and McCauley Springs--are composed solely of meteoric water, are relatively dilute and contain only modest concentrations of 1 ithium and boron. The $\mathrm{Na}-\mathrm{K}-\mathrm{Ca} B=4 / 3$ temperatures are all $<100^{\circ} \mathrm{C}$ and, except for San Antonio, within $25^{\circ} \mathrm{C}$ of the measured spring temperature. These data indicate that the thermal meteoric waters are merely heated surface ground water in equilibrium at the measured spring temperature. Contrary to Trainer, ${ }^{21}$ these springs are probably not in equilibrium with quartz because the quartz temperature estimates appear to be too high.

The hot mineral springs at Soda Dam contain substantial quantities of boron, lithium, fluoride, and arsenic; the ratios of boron/chloride and lithium/chloride are quite high. Estimation of a deep reservoir temperature 
TABLE III

CHEMICAL GEOTHERMOMETRY OF THERMAL ANO NONTHERMAL WATERS

OF THE LOS ALAMOS AND VALLES CALDERA REGION

\begin{tabular}{|c|c|c|c|c|c|c|c|}
\hline \multirow[b]{2}{*}{ No. } & \multirow[b]{2}{*}{ Name } & \multirow[b]{2}{*}{$\begin{array}{c}\text { Mea sured } \\
\text { Temp. } \\
\left({ }^{\circ} \mathrm{C}\right) \\
\end{array}$} & \multirow[b]{2}{*}{ Quartz } & \multirow[b]{2}{*}{$\begin{array}{c}\text { Amor phous } \\
\mathrm{SiO}_{2} \\
\end{array}$} & \multicolumn{3}{|c|}{$\mathrm{Na}-\mathrm{K}-\mathrm{Ca}$} \\
\hline & & & & & $\underline{B}=4 / 3$ & $B=1 / 3$ & $\begin{array}{c}\mathrm{Mg} \\
\text { Corrected } \\
\end{array}$ \\
\hline$V A-1$ & Spence Hot Spg & 45 & 112 & -2.3 & 55 & & \\
\hline$V A-3$ & McCauley Spg & 31 & 105 & -9.3 & 27 & & \\
\hline$V A-4$ & San Antonio Hot Spg & 42 & 124 & 5.8 & 71 & & 71 \\
\hline VA-5 & Soda Dam Spg & 47 & 95 & -20.0 & 178 & 220 & 160 \\
\hline LA-1 & Gallery Spg & 11 & & & 34 & & \\
\hline LA-2 & T-3 well & 13 & & & 34 & & \\
\hline LA-3 & $T-2$ well & 11 & & & 18 & & \\
\hline$L A-4$ & Sacred Spg & 14 & & & 39 & & \\
\hline$L A-5$ & Basalt Spg & 15 & & & 37 & & \\
\hline LA-6 & L-6 we 11 & 27 & 83 & -49.0 & 59 & & \\
\hline LA-7 & L-1B well & 30 & 86 & -26.0 & 75 & & 75 \\
\hline$L A-10$ & PM-2 well & 23.5 & & & 38 & & \\
\hline LA-11 & PM-1 well & 28 & & & 45 & & \\
\hline LA-12 & G-6 well & 30.5 & & & 38 & & \\
\hline LA-14 & G-4 well & 26 & & & 33 & & \\
\hline$L A-16$ & G-2 well & 30 & & & 56 & & \\
\hline LA- 17 & G-1A well & 28 & & & 56 & & \\
\hline$L A-18$ & G-1 well & 26 & & & 55 & & \\
\hline$L A-19$ & Spg, White Rock Canyon & 19 & & & 30 & & \\
\hline \multicolumn{8}{|c|}{ Mariner and others, 1977} \\
\hline & Unnamed Mineral Spg & 11 & 58 & -49.0 & 206 & 162 & 37 \\
\hline & Unnamed Warm Spg & 25 & 55 & -54.0 & 158 & 144 & 84 \\
\hline & Unnamed Mineral Spg & 15 & 60 & -46.0 & 155 & 155 & 70 \\
\hline
\end{tabular}


from the $\mathrm{Na}-\mathrm{K}-\mathrm{Ca}$ (Mg corrected) geothermometer is $160^{\circ} \mathrm{C}$, considerably greater than the discharge temperature of $48^{\circ} \mathrm{C}$. These data suggest that the waters of Soda Dam are derivatives of some moderate- to high-temperature geothermal system. Trainer ${ }^{11}$ has indicated that they may be derived from the $260^{\circ} \mathrm{C}$ geothermal system within Valles Caldera.

In contrast, the mineral waters near San Ysidro have lower boron/chloride and lithium/chloride ratios and yield $\mathrm{Na}-\mathrm{K}-\mathrm{Ca}$ (Mg corrected) temperatures of $<85^{\circ} \mathrm{C}$. Mariner et al. ${ }^{22}$ feel these fluids are probably not derived from a high-temperature geothermal system. We suggest that the waters at San Ysidro issue from a unique geothermal system in that area.

The Los Alamos springs and wellis are composed of meteoric water, are relatively low in dissolved solids, and indicate no geothermal potential except for wells $L-1 B$ and $L-6$. In general, these last two waters contain anomalous quantities of lithium, boron, fluoride, and arsenic. In addition, $L-1 B$ and L-6 give anomalously high $\mathrm{Na}-\mathrm{K}-\mathrm{Ca} B=4 / 3$ geotemperature estimates that ind $\mathrm{i}-$ cate they may be mixed waters containing a small fraction of deep thermal/mineral water. The composition and temperature of this hypothetical deep fluid cannot be guessed with the present data. However, the electrical resistivity data indicate that such a deep fluid exists. 6

Because the waters of $L-6$, and particularly $L-1 B$, have a different source aquifer and isotopic signature than waters of the other deep wells, it is easy to assume that the anomalies in chemical composition of $L-1 B$ and $L-6$ merely result from the unique composition of the confined aquifer. However, two facts argue against this simple explanation. (1) Well L-6, although it appears to be a mixture of waters from the Main and Confined Aquifers, has more arsenic than any of the other wells. This suggests a separate source for the arsenic. (2) The Na-K-Ca geothermometry suggests that wells L-1B and L-6 are picking up a small component of deeper, hotter water.

We speculate that this fluid leaks upwards along the set of northtrending normal faults ${ }^{1}$ that cut the east side of the Pajarito Plateau near the Los Alamos well field. We suspect that this fluid is dispersed locally into the deep confined aquifer of the Tesuque Member of the Santa Fe formation. The Los Alamos well field lies at the south end of a belt of normal faults that cut sediments of both the Puye and Santa Fe formations and these faults may be surface expressions of a much deeper fault system. The large volume of the diluting Santa Fe aquifers masks the composition of the less 
voluminous deep fluid. Possibly, the deep fluid is mineralized water that originates in deeply buried Paleozoic sediments at the base of the graben. If such a Paleozoic section exists, it is at a maximum depth of roughly $3075 \mathrm{~m}$ beneath the top of the Pajarito Plateau according to the gravity data of Budding. 5 This means the fluid rises a maximum height of about $2000 \mathrm{~m}$ before mixing. A similar idea was offered by Purtymun ${ }^{23}$ to explain the occurrence of the arsenic, fluoride-rich component entering wells $L-1 B$ and $L-6$ of the Los Alamos well field. The model presented here is very simplistic. In reality there may be several stages of mixing within intermediate level aquifers before the deep fluid ever enters the L-1B well bore.

\section{CONCLUSIONS}

The Los Alamos area contains no springs or deep aquifers composed solely of thermal water of deep origin. Isotope data indicate all waters of the Los Alamos area are of meteoric origin. The two aquifers supplying most of the potable water for Los Alamos have different recharge areas. Chemical data and arguments based on geothermometry suggest that a small fraction of thermal/mineral water of deep origin is mixing with waters of the Los Alamos well field. We feel this deep water probably rises along high-angle faults on the eastern side of the Pajarito Plateau. Available electrical resistivity data ${ }^{6}$ indicate that such a deep fluid probably exists.

\section{ACKNOWLEDGMENTS}

The authors are extremely grateful for the knowledge and unpublished data provided by Bill Purtymun. Hans Sheline helped collect a few of the waters.

\section{REFERENCES}

1. R. L. Smith, R. A. Bailey, and C. S. Ross, "Geologic Map of the Jemez Mountains, New Mexico," U.S. Geol. Surv. Misc. Geologic Invest. Map I-571 (1970).

2. K. Manley, "Stratigraphy and Structure of the Española Basin, Rio Grande Rift, New Mexico," in Rio Grande Rift: Tectonics and Magmatism, R. E. Riecker, Ed., Am. Geophy. Union, Wash. D.C., (1979) 438 pp.

3. V. C. Kelley, "Geology of the Española Basin, New Mexico," N. M. Bur. Mines Miner. Resour. Geologic Map 48 (1978). 
4. G. H. Wood and S. A. Northrup, "Geology of Naciemento Mountains, San Pedro Mountain and Adjacent Plateaus in Parts of Sandoval and Rio Arriba Counties, New Mexico," U.S. Geol. Surv. Oil and Gas Inv. Prel im. Map 57 (1946).

5. A. J. Budding, "Gravity Survey of the Pajarito Plateau Los Alamos and Santa Fe Counties, New Mexico," Los Alamos Scientific Laboratory report LA-7419-MS (1978).

6. Williston, McNeil, and Associates, "A Time Domain Survey of the Los Alamos Region, New Mexico," Los Al amos Scientific Laboratory report, LA-7657-MS (1979).

7. M. Reiter, C. L. Edwards, H. Hartman, and C. Weidman, "Terrestrial Heat Flow Along the Rio Grande Rift, New Mexico and Southern Colorado," Geol. Soc. Amer. Bu11. 86, 811-818 (1975).

8. M. Reiter, C. Weidman, C. L. Edwards, and H. Hartman, "Subsurface Temperature Data in Jemez Mountains, New Mexico," N. M. Bur. Mines Miner. Resour. Cir. 151 (1976) 16 pp.

9. R. L. Griggs, "Geology and Ground-Water Resources of the Los Al amos Area, New Mexico, with a section on Quality of Water by J. D. Hem,"U.S. Geol. Sur. Water-Supply paper 1753 (1954) $107 \mathrm{pp}$.

10. W. D. Purtymun and J. B. Cooper, "Development of Ground-water Supplies on the Pajarito Plateau, Los Alamos County, New Mexico," U.S. Geol. Surv. Prof. Paper 650-B, B149-B153 (1969).

11. F. W. Trainer, "Geohydrologic Data from the Jemez Mountains and Vicinity, North-Central New Mexico," U.S. Geol. Surv. Water Resour. Invest. 77-131 (1978) $146 \mathrm{pp}$.

12. W. D. Purtymun, F. G. West, and W. H. Adams, "Preliminary Study of the Quality of Water in the Drainage Area of the Jemez River and Rio Guadalupe," Los Alamos Scientific Laboratory report LA-5595-MS (1974).

13. W. D. Purtymun and S. Johansen, General Geohydrology of the Pajarito Plateau, N. M. Geol. Soc. Guidebook, 25th Field Conf., Ghost Ranch (1974) pp. 347-349.

14. D. E. White, I. Barnes, and J. R. O'Neil, "Thermal and Mineral Waters of Nonmeteoric Origin, California Coast Ranges," Geol. Soc. Am.. Bull. 84, 547-560 (1973).

15. H. Craig, G. Boato, and D. E. White, "Isotopic Geochemistry of Thermal Waters," in Proc. 2nd Conf. on Nuclear Processes in Geologic Settings, (1956) p. 29.

16. D. E. White, "Magmatic, Connate, and Metamorphic Waters," Geol. Soc. Am. Bu11. 68, 1659-1682 (1957). 
17. R. O. Fournier and J. J. Rowe, "Estimation of Underground Temperatures from the Silica Content of Water from Hot Springs and Wet-Steam Wells," Am. J. Sci. 264, 685-697 (1966).

18. R. O. Fournier and A. H. Truesdel1, "An Empirical Na-K-Ca Geothermometer for Natural Waters," Geochim. Cosmochim. Acta 37, 1255-1275 (1973).

19. R. 0. Fournier and R. W. Potter, "A Magnesium Correction for the Na-K-Ca Chemical Geothermometer," U.S. Geol. Surv. open-file report 78-986 (1978) $24 \mathrm{pp}$.

20. R. 0. Fournier and A. H. Truesdell, "Geochemical Indicators of Subsurface Temperature - Part 2, Estimation of Temperature and Fraction of Hot Water Mixed with Cold Water," U.S. Geol. Surv. J. Res. 2, 263-270 (1974).

21. F. W. Trainer, Ground Water in the Southwestern Part of the Jemez Mountains Volcanic Region, New Mexico, N. M. Geol. Soc. Guidebook, 25th Field Conf., Ghost Ranch (1974) pp. 337-345.

22. R. H. Mariner, T. S. Presser, and W. C. Evans, "Chemical, Isotopic, and Gas Compositions of Selected Thermal Springs in Arizona, New Mexico, and Utah," U.S. Geol. Surv. open-file report 77-654 (1977) 42 p.

23. W. D. Purtymun, "Hydrologic Characteristics of the Los Alamos Well Field, with Reference to the Occurrence of Arsenic in Wel1 La-6," Los Alamos Scientific Laboratory report LA-7012-MS (1977). 